\title{
Evidences of $E l$ Niño Effects on the Mullet Fishery of the Patos Lagoon Estuary
}

\author{
João Paes Vieira ${ }^{1^{*}}$, Alexandre Miranda Garcia ${ }^{2}$, and Alice Marlene Grimm ${ }^{3}$ \\ ${ }^{I}$ Fundação Universidade Federal de Rio Grande - FURG; Departamento de Oceanografia; Laboratório de \\ Ictiologia; C. P. 474; Rio Grande - RS - Brasil. ${ }^{2}$ Universidade Federal do Rio Grande do Sul; Instituto de Pesquisas \\ Hidráulicas; CP 15029; Porto Alegre - RS - Brasil. ${ }^{3}$ Universidade Federal do Paraná; Departamento de Física; \\ Curitiba - PR - Brasil
}

\begin{abstract}
Based on biological and meteorological long-term database (1979-1983 and 1996-2000), we analyzed the variation in the juvenile recruitment and artisanal fishery landings of the mullet (Mugil platanus) in the Patos Lagoon estuary and its relationships with the regional rainfall and estuarine salinity anomalies during two strong El Niño events (1982-83 and 1997-98). Juvenile and adult mullets declined in abundance under the high rainfall and near-zero salinity that prevailed in the estuary during both El Niño events. We proposed two different hypotheses to explain the El Niño-induced effects on the juvenile and adult stages of the mullet in the estuary. First, high freshwater outflow during a very strong El Niño might render ineffective the mechanism of passive immigration of juvenile mullets into the estuary, which can lead to their decline in the estuary during El Niño events. Second, near-zero salinity at the estuarine area along several months during strong El Niño events could lead to higher spatial dispersion of the maturing mullet during their migration to the ocean, resulting in smaller shoals of individuals and, consequently, lower catches by artisanal fishermen.
\end{abstract}

Key words: Artisanal fishery, ENSO, climatic effects, long-term studies, PELD, LTER

\section{INTRODUCTION}

El Niño events represent periods of anomalous conditions occurring in the tropical Pacific Ocean every three to seven years (Sverdrup et al., 2005), and its climatic effects can be felt worldwide (Glantz, 2000). For example, El Niño events are associated with higher than average rainfall in southern Brazil (Grimm et al., 1998; Grimm et al., 2000). Excessive rainfall triggered by El Niño events over the large drainage basin $\left(201,626 \mathrm{~km}^{2}\right)$ of Patos Lagoon greatly increases freshwater inflow into the lagoon $\left(10,360 \mathrm{~km}^{2}\right)$, resulting in the transport of the estuarine plume several kilometers into the adjacent coastal marine area (Garcia, 1996; Moller et al., 2001).

Previous investigations (Garcia et al., 2004) have shown that high freshwater discharges indirectly triggered by El Niño events cause profound effects on the fish assemblages of Patos Lagoon. They flush freshwater fishes into the estuarine zone from the limnic portion of the Patos Lagoon, and move estuarine resident fishes out of the estuary towards the adjacent marine area. Also, the high freshwater outflow through the narrow mouth of the estuary impairs the entrance in abundance of marine spawning species that predictably use the estuary as nursery grounds for their juveniles. Mullets, in particular, are an important fishery resource in this region (Reis and D'incao, 2000). 
Previous studies have shown that juvenile mullets are negatively affected by $\mathrm{El}$ Niño conditions (Garcia et al., 2001). These studies, however, focused only on the structure and dynamics of the juvenile fish assemblage in terms of diversity (e.g., Garcia and Vieira, 2001) and recruitment patterns (e.g., Garcia et al., 2003). Currently, there is no information concerning the effects on the adult fish populations that sustain artisanal fisheries in the estuary. Therefore, it is important to investigate on a long-term basis the association between fishery catches of adult estuarine stocks and abiotic disturbances induced by El Niño events in the Patos Lagoon estuary. Such knowledge can provide new insights and subsidies to help the fishery management of the increasingly impoverished artisanal estuarine fishery in this region (Reis and D'incao, 2000). Management of commercially exploited fish stocks is severely hampered without some understanding of the processes that drive recruitment variability and adult fish stocks on a long-term basis (Cushing, 1975; Tyler, 1992).

Based on biological and meteorological long-term database (1979-1983 and 1996-2000), we conducted the analyzes of the variation in the juvenile recruitment and artisanal fishery landings of the mullet (Mugil platanus) in the Patos Lagoon estuary and its relationships with regional rainfall and estuarine salinity anomalies during the two strong El Niño events 1982-83 and 1997-98.

\section{MATERIALS AND METHODS}

\section{Study site}

The Patos Lagoon $\left(32^{\circ} \mathrm{S} 49^{\circ} \mathrm{W}\right)$ is ca. $250 \mathrm{~km}$ long and $60 \mathrm{~km}$ wide, covering an area of $10,360 \mathrm{~km}^{2}$ along the coastal plain of Rio Grande do Sul in southern Brazil (Fig. 1). The estuarine zone is restricted to the southern portion of the lagoon (ca. $10 \%$ of total area) and is connected to the ocean via a channel bordered by jetties $(4 \mathrm{~km}$ long and $740 \mathrm{~m}$ wide) constructed to stabilize the mouth of the estuary and to allow the navigation along the entrance channel (Fig. 1c). Apart from a navigation channel with $20 \mathrm{~m}$ in depth, about $80 \%$ of this area is less than $2 \mathrm{~m}$.

Tidal influence on hydrodynamic characteristics is minimal (mean tidal amplitude is $0.47 \mathrm{~m}$ ) (Seeliger, 2001). Rather, wind patterns and seasonal pulses of freshwater inflow influence patterns of water circulation and salinity (longitudinal and vertical). Dominant northeasterly winds (mean $5 \mathrm{~m} \mathrm{~s}^{-1}$ ) promote flushing out of the estuary, but southerly winds (mean $8 \mathrm{~m} \mathrm{~s}^{-1}$ ) tend to move seawater into the lower lagoon reach. The lagoon's drainage basin $\left(201,626 \mathrm{~km}^{2}\right)$ is one of the largest in Latin America (Fig. 1a). Freshwater discharge varies seasonally, with high discharge in late winter and early spring followed by moderate discharge through summer and autumn. The mean annual discharge is ca. $2,000 \mathrm{~m}^{3} \mathrm{~s}^{-1}$, although large year-to-year variation can occur (700 to $3,000 \mathrm{~m}^{3}$ $\mathrm{s}^{-1}$ ) (Moller et al., 2001). During El Niño episodes, runoff greatly exceeds average values and the lagoon waters can remain fresh for several months (Moller et al., 2001; Garcia et al., 2003).

The lagoon and adjacent coastal area support one of the most important fisheries in the warmtemperate southwestern Atlantic, with about 3,500 artisanal and 3,000 industrial fishermen temporarily or permanently involved in fishing activities in this region (Reis and D'incao, 2000; Haimovici et al., 1996). The estuary is an important nursery for several of the most important species in these fisheries. The mullet Mugil platanus is one of the most frequent and abundant fish species using this area, representing a traditional target for the estuarine artisanal fishery (Chao et al., 1985; Vieira and Castello, 1996).

According to Vieira (1991), juvenile M. platanus occur year-round in the estuarine and adjacent marine habitats of the Patos Lagoon estuary and the species appear to be well-adapted to large fluctuations in temperature and salinity. The importance of $M$. platanus in the fishery of southern Brazil (Reis and D'incao, 2000) and the dominance of juveniles in the shallow waters of Patos Lagoon estuary suggest that this ecosystem functions as an important nursery ground (Vieira, 1991; Vieira and Scalabrin, 1991).

\section{Field sampling and data analyses}

Juvenile mullets (Mugil platanus) were sampled using a $9 \times 1.5 \mathrm{~m}$ beach seine $(13 \mathrm{~mm}$ bar mesh in the wings and $5 \mathrm{~mm}$ in the center $3-\mathrm{m}$ section) that was pulled to cover an area of approximately 60 $\mathrm{m}^{2}$. Survey stations were located in shallow waters of the Patos Lagoon estuary (Fig. 1). The number of survey stations varied between the two sampling periods, with four to six survey stations during 1979-1983 and four during 1996-2000. Each sample was composed of three beach seine 
hauls. Seven samples (21 hauls) were made during each season within two periods: winter 1979 to spring 1983 (the one exception was summer 1983 with 15 hauls), and winter 1996 to spring 2000.

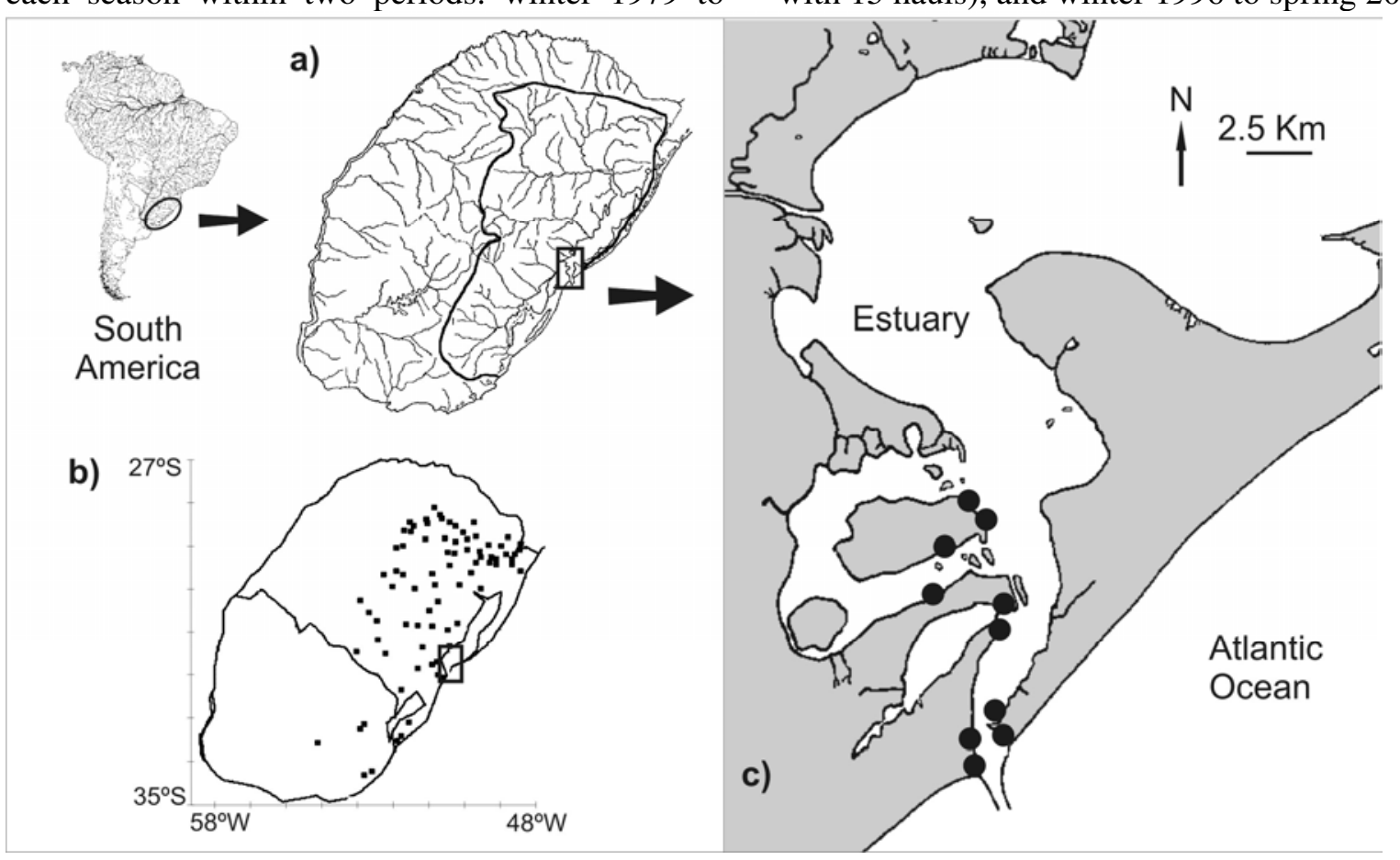

Figure 1 - a) Drainage basin of the Patos Lagoon (bold line) located in southern South America, and the location of the estuarine area (box); b) spatial distribution of the 81 meteorological stations along the drainage basin; c) estuarine area showing beach survey stations (dots).

Samples were grouped by seasons as follows: summer (Jan to Mar), autumn (Apr to Jun), winter (Jul to Sep) and spring (Oct to Dec). These experimental data (beach seine hauls) were obtained from two large projects: BELAP ("Bioecologia dos peixes e decápodos do estuário da Lagoa dos Patos e região costeira adjacente"), carried out from 1979 to 1984, and PELD ("Pesquisas Ecológicas de Longa Duração Fishes"), which started in 1996.

Rainfall data were obtained from a database of 22 years (1979 to 2000) of precipitation in 81 meteorological stations scattered in the Patos Lagoon drainage basin (Fig. 1b). Salinity data were obtained from a 10-yr database (1978-1983 and 1996-2000) of monthly measurements in the same sampling stations used to collect fishes (Fig. 1c). Based on the rainfall and salinity distribution and anomalies in the Patos Lagoon, the following group of seasons were used to set the temporal limits of the El Niño events: spring 1982 to winter 1983 (1982-83 El Niño) and spring 1997 to winter 1998 (1997-98 El Niño). We compared juvenile recruitment and fishery statistics of mullets between $E l$ Niño vs. non-El Niño periods to examine correlations between the population and meteorological (rainfall) and hydrological (salinity) conditions associated with El Niño events.

Mullet fishery statistics from the Patos Lagoon were collected regularly by the Federal Environmental Agency of Brazil (IBAMACEPERG/RS). Although, these fishery data probably underestimate actual catches $(\sim 25 \%)$ and lack specific information on the catch effort, they nonetheless can be useful to indicate relative landings. This because, when compared to coastal fishery in the Patos Lagoon, there had been no major changes in the fishing effort, gear or fishing techniques in the mullet artisanal fishery of this region (Reis et al., 1994; Haimovici 1996; Reis and D'Incao 2000). Therefore, it seems reasonable to assume that artisanal catch data alone provided an adequate relative abundance index to investigate El Niño effects on the mullet estuarine population. 
Three mullet species (Mugil platanus, M. curema, and $M$. gaimardianus) occur in the region (Chao et al., 1985; Garcia et al., 2004), but fishes landing data did not distinguish among species. Some studies indicated that juveniles $M$. platanus are the most abundant mullet species in the region (Vieira, 1991), and this is the only species to remain in the estuarine zone throughout the year, where they grow till reach the adult size (Vieira and Scalabrin, 1991). Therefore, we assumed that the Patos Lagoon mullet fishery data were represented exclusively by $M$. platanus.

For each sampling period (1979-1983 and 19962000), we performed linear regression between juvenile recruitment and catch statistics data and environmental parameters (rainfall and salinity). Juvenile recruitment data were the total relative abundance of the mullets obtained by beach seine hauls (as described earlier). Catch statistics data (sub-adults and adults) were the total landing (in tons) of mullets in the Patos Lagoon (Rio Grande do Sul state). We used only summer and autumn seasons for the fishery data, because the fishery effort was most intense during this period (Vieira and Scalabrin, 1991).

\section{RESULTS}

The fishery landing catch of adult mullets fluctuated 4-fold over the study period, with the late 1990s showing a decrease of about 50\% relative to the early 1980 s (Fig. 2b). The relative abundance of juvenile mullets revealed large within- and between-year variation, and a weak trend of declining abundance in recent years (Fig. 2c). Nevertheless, both juvenile and adult mullets declined in abundance under the high rainfall and near-zero salinity that prevailed in the estuary during both El Niño events (Fig. 2).

Juvenile and adult mullets were negatively correlated with rainfall during both sampling decades (Fig. 3a,b), with statistically significant regression coefficients (except for the landing catch data of 1996-2000). Conversely, juvenile and adult mullets were positively correlated with salinity during both decades, with statistically significant regression coefficients for juvenile abundance but not for landing data (Fig. 3c,d). In general, extreme cases of high rainfall and low salinity during $\mathrm{El}$ Niño events were associated with the lowest juvenile abundances and fishery catches of mullets.

\section{DISCUSSION}

Both El Niño events were correlated with the interannual variability in abundance of the mullets in the Patos Lagoon estuary. Relative abundances of juveniles and fishery catch of adults declined during the high rainfall and low salinity conditions associated with both El Niño events. Two hypotheses could explain these apparently negative effects on the juvenile and adult stages of the mullet in the estuary:

a) Mugil platanus spawns offshore along the southern Brazilian coast and their recruits $(<50$ $\mathrm{mm}$ ) used net upstream circulation at the bottom of the water column at the estuary mouth for transport into the estuary (Vieira, 1991). As previously proposed by Garcia et al., (2001), high freshwater outflow during a very strong $\mathrm{El} \mathrm{Niño}$ could render ineffective the mechanism of passive immigration of juvenile mullets into the estuary, which could lead to its decline in the estuary during El Niño events.

b) Mullet recruits remain in the shallow waters of the estuary until reaching maturity, after which (April-May) they join the adult mullet population and start a reproductive migration towards offshore spawning grounds. The artisanal mullet fishery is most intense and effective during the formation of large schools of maturing adults as they prepare and initiate their outward migration. According to Vieira and Scalabrin (1991), the reproductive migration of $M$. platanus is trigged by a sudden drop of water temperature below $19^{\circ} \mathrm{C}$ and the intrusion of marine water into the estuary. Based on the present results it could be hypothesized that the near-zero salinity at the estuarine area along several months, triggered by the elevated rainfall associated with El Niño events, negatively affecs the pre-spawning aggregation and migration of maturing mullet adults. It could be possible that the schooling behavior of this fish renders more ineffective in response to a less intrusion of salty water during the anomalous El Niño conditions. Higher spatial dispersion of the maturing mullet during their offshore migration could result in smaller shoals of individuals, which in turn, could explain the lower catch obtained by artisanal estuarine fishermen during both El Niño events. 


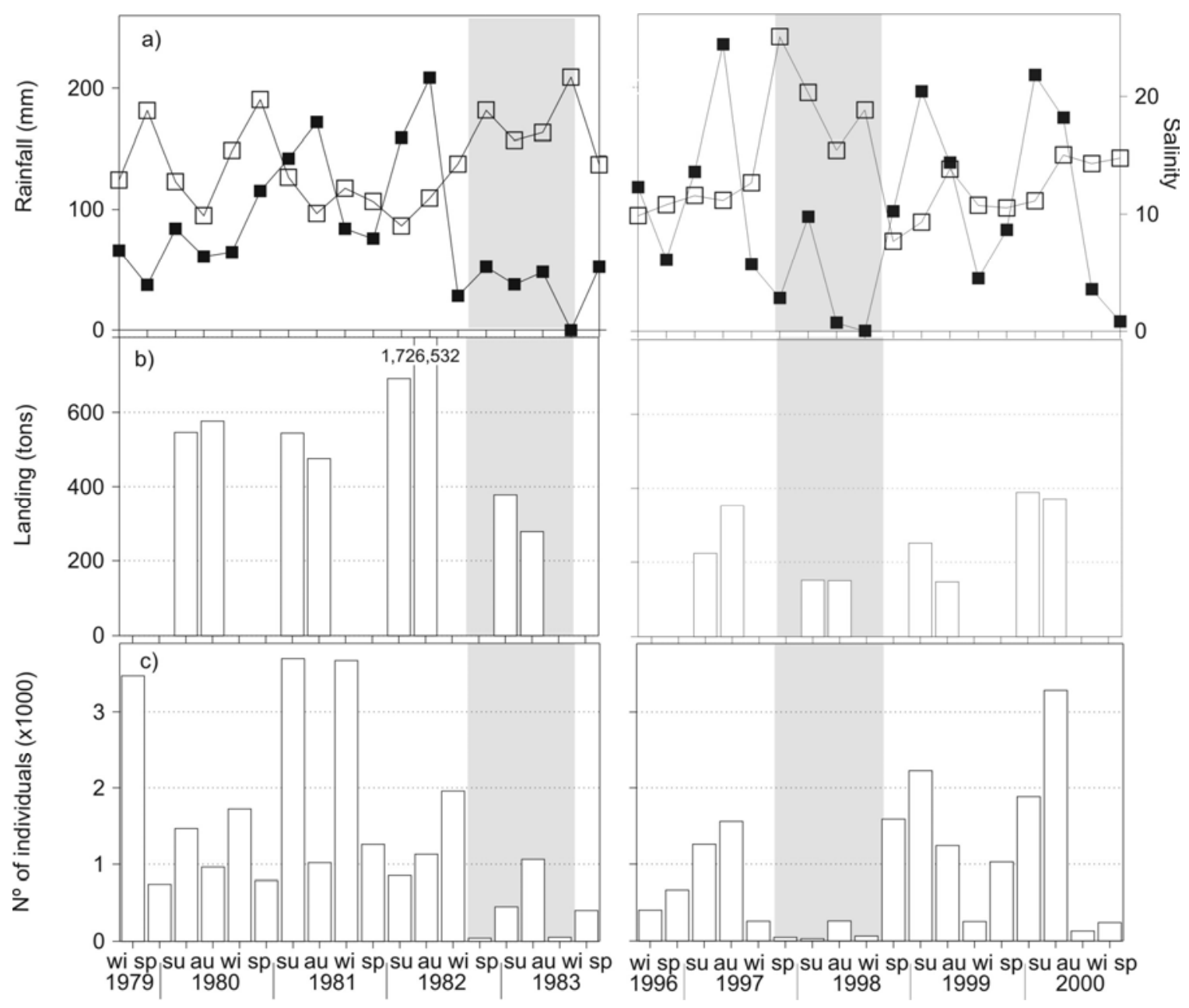

Figure 2 - Seasonal fluctuation in the two sampling periods (1979-1983 and 1996-2000) of (a) rainfall (empty square) in the drainage basin of the Patos Lagoon, and salinity (filled square) in the estuarine area, (b) landing data of mullets in the Patos Lagoon, and (c) relative abundance of mullet juveniles (Mugil platanus) in the estuarine area. The shaded area represents El Niño periods.

Considering that there was no catch effort available to calculate CPUE estimates for the mullet fishery in Patos Lagoon, it could be argued that the observed correlations obtained for the fish landing of adult mullets could be related to unknown historical changes in catch effort. However, when compared to the coastal fishery, which had shown significant historical changes in fishing effort, techniques and gears, the artisanal mullet fishery seemed to be much more conservative (Reis et al., 1994; Haimovici 1996). It had shown no significant historical changes in the fishing effort, gears and fishing techniques. In fact, mullet fishery in Patos Lagoon estuary operate, by and large, as a traditional and subsistence enterprise (Reis and D'incao 2000), where the number of fishermen involved, the fish gear (gillnets), the fishing techniques and the number of fishing days remain fairly similar across years and decades. Therefore, it could be reasonable to suppose that possible changes in the fishing effort should be of less magnitude than the changes in relative abundance induced by both $E l$ Niño events.

Several studies in the oceanic regions have indicated a significant influence of the El Niño events on the reproductive success recruitment variability and spatial distribution of the fishery 
resources (Lehodey et al., 1997; Lu et al., 1998;

Arcos et al., 2001; Yánez et al., 2001).
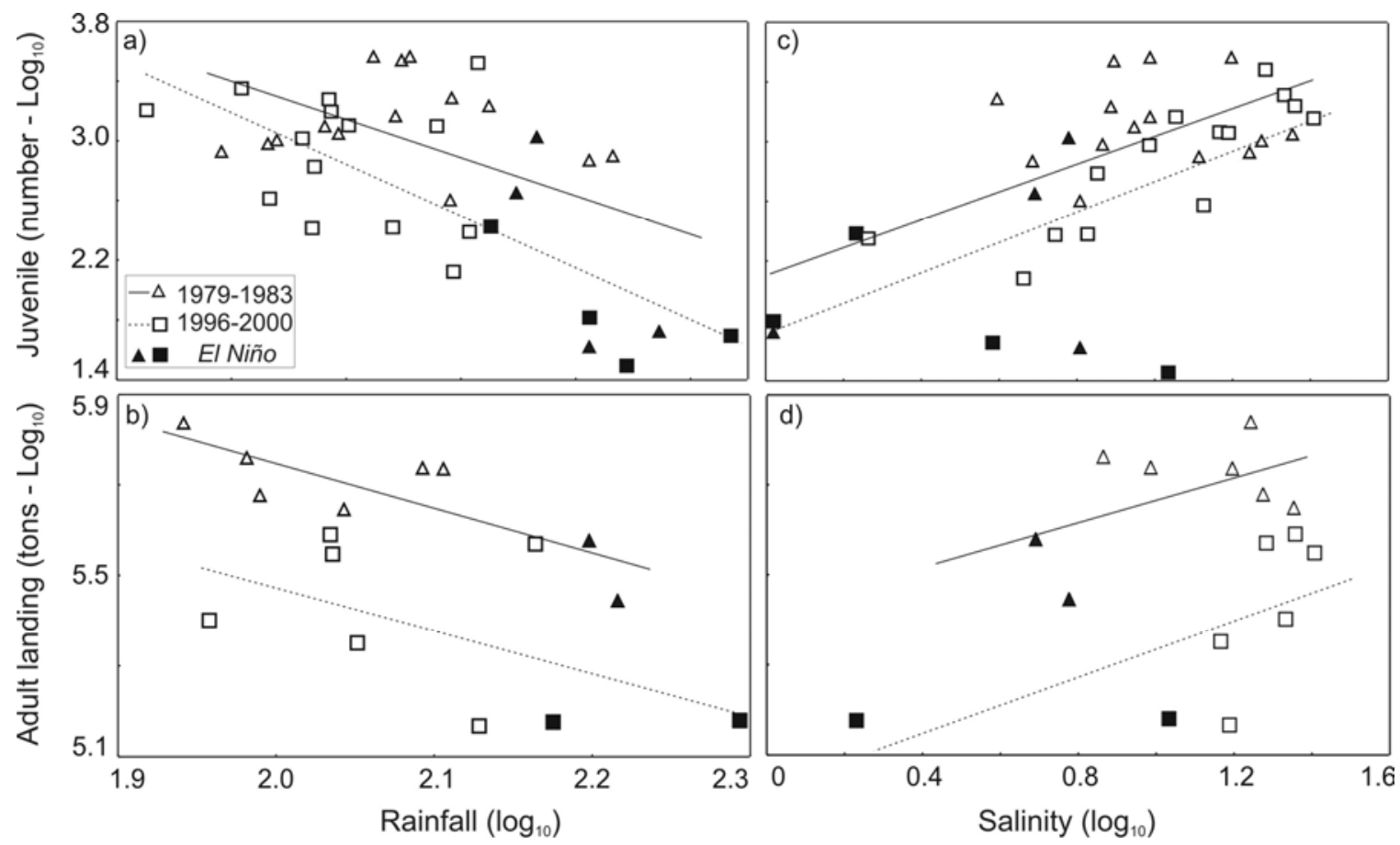

Figure 3 - Relationships of relative abundance of juvenile and fish landing of adult mullets to rainfall (a,b) and salinity (c,d) during the 1979-1983 (triangle - solid line) and 19962000 (square - dashed line) periods. El Niño conditions are shown by filled symbols. Regression coefficients: (a) 1979-1983: $\mathrm{r}=-0.53 ; \mathrm{p}=0.022$ and 1996-2000: $\mathrm{r}=-0.73$; $\mathrm{p}=0.000$, (b) 1979-1983: $\mathrm{r}=-0.82 ; \mathrm{p}=0.013$ and 1996-2000: $\mathrm{r}=-0.54 ; \mathrm{p}=0.166$, (c) 1979-1983: $\mathrm{r}=0.54 ; \mathrm{p}=0.020$ and 1996-2000: $\mathrm{r}=0.69 ; \mathrm{p}=0.001$, and (d) 19791983: $\mathrm{r}=0.51 ; \mathrm{p}=0.194$ and 1996-2000: $\mathrm{r}=0.64 ; \mathrm{p}=0.083$.

For instance, Hollowed et al. (2001) showed that the Pacific decadal oscillation and the El Niño southern oscillation could play important roles in governing the year-class strength of several Northeast Pacific marine fish stocks. Some species (e.g., Pacific hake, Gulf of Alaska walleye pollock, and Gulf of Alaska Pacific cod) showed higher incidence of strong year classes in years associated with El Niño conditions. Most studies addressing the effects of the El Niño on fishery resources have been conducted in oceanic and coastal waters, and until recently similar evidence has been lacking for estuaries. As emphasized by Bakun (1996), recruitment variability may be induced by the differential transport of marine larvae into estuarine nursery grounds and variation in freshwater discharge into estuaries. Freshwater inflow may regulate the size and productivity of brackish habitats, as well as water flow patterns that affect fish movement into and out of estuarine systems.

In conclusion, El Niño events seemed to affect the inter-annual variability in abundance of the mullet Mugil platanus during two crucial phases of its life cycle: the juvenile recruitment into the estuary and the reproductive migration of mature adults out to the sea. Predictive models of the juvenile recruitment and the management of the fishery mullet stock in Patos Lagoon estuary and also others estuarine related species, should take into account indicators of the onset of El Niño conditions in the Pacific Ocean and its meteorological effects in southern Brazil. Since 1985, continued monitoring of El Niño conditions in the Pacific Ocean has been carried by international research agencies (e.g., TOGA and TAO projects), which have led to more accurate predictions of the onset of $E l$ Niño events 
(Sverdrup et al., 2005). More accurate predictions of $E l$ Niño conditions combined with the knowledge of its climatic effects on the mullet population could help fishery managers and decision makers to anticipate positive and negative impacts of this phenomenon on the artisanal mullet fishery of the Patos Lagoon estuary.

\section{ACKNOWLEDGMENTS}

We thank researchers and the staff from the FURG Ichthyology Lab. that collected the historical data (1979-1983), Lisiane A. Ramos for collecting data between August 1996 and August 1997, and other colleagues who assisted in the field. This study received financial support from the Coordenadoria de Aperfeiçoamento de Pessoal de Nível Superior - CAPES (Brazil), the Conselho Nacional de Desenvolvimento Científico e Tecnológico CNPq (Brazil), Brazilian Long Term Ecological Research (LTER) and the Inter American Institute for Global Change Research (IAI) through a fellowship granted by the SACC/Consortium (CRN-019).

\section{RESUMO}

Episódios El Niño ocorrem na região tropical do Oceano Pacífico e estão associados com o aumento da descarga continental de água na Lagoa dos Patos $\left(10.360 \mathrm{~km}^{2}\right)$ e sua região estuarina (971 $\mathrm{km}^{2}$ ). A partir de um banco de dados meteorológicos e biológicos de longo prazo (19791983 e 1996-2000), este trabalho investiga as variações no recrutamento de juvenis e no desembarque da pesca artesanal da tainha (Mugil platanus) no estuário da Lagoa dos Patos e suas relações com anomalias regionais de chuva e anomalias locais de salinidade durante dois fortes episódios El Niño (1982-1983 e 1997-1998). Tanto os juvenis quanto a captura dos adultos na pesca artesanal diminuíram em abundância durante as chuvas excessivas e salinidades próximas a zero que prevaleceram no estuário durante ambos eventos climáticos. Duas hipóteses são sugeridas para explicar os efeitos ocasionados pelo El Niño sobre as fases juvenis e adultas da tainha no estuário da Lagoa dos Patos. Primeiro, a elevada descarga continental durante forte eventos El Niño poderia afetar negativamente o transporte passivo de juvenis de tainha para o interior do estuário, o que levaria ao declínio de juvenis na região nesse período. Segundo, as salinidades próximas a zero durante vários meses no estuário durante forte eventos El Niño poderia acarretar maior dispersão dos cardumes de tainhas adultas durante a sua migração reprodutiva para o mar, resultando em menores capturas pelos pescadores artesanais da região.

\section{REFERENCES}

Arcos, D. F.; Cubillos, L. A. and Núñez, S. P. (2001), The jack mackerel fishery and El Niño 1998-98 effects off Chile. Prog. Oceanogr., 49:597-617.

Bakun, A. (1996), Patterns in the ocean: ocean processes and marine population dynamics, Vol. California Sea Grant College System, NOAA in cooperation with Centro de Investigaciones Biologicas del Noroeste

Chao, L. H.; Pereira, L. E. and Vieira, J. P. (1985), Estuarine fish community of the dos Patos Lagoon, Brazil. A baseline study. In: Yanez-Arancibia, A. (ed) Fish Community Ecology in Estuaries and Coastal Lagoons: Towards an Ecoystem Integration. DR (R) UNAM Press, Mexico, pp 429-450.

Cushing, D. H. (1975), Marine Ecology and Fisheries, Vol. Cambridge University Press, Cambridge.

Garcia, A. M. and Vieira, J. P. (2001), O Aumento da diversidade de peixes no estuario da Lagoa dos Patos durante o episodio El Nino 1997-1998. Atlântica, 23

Garcia, A. M.; Vieira, J. P. and Winemiller, K. O. (2001), Dynamics of the shallow-water fish assemblage of the Patos Lagoon estuary (Brazil) during cold and warm ENSO episodes. J. Fish Biol., 59:1218-1238.

Garcia, A. M.; Vieira, J. P. and Winemiller, K. O. (2003), Effects of 1997-1998 El Niño on the dynamics of the shallow-water fish assemblage of the Patos Lagoon estuary (Brazil). Est. Coast. Shelf Sci., 57:489-500.

Garcia, A. M.; Vieira, J. P.; Winemiller, K. O. and Grimm, A. M. (2004), Comparison of the 1982-1983 and 1997-1998 El Niño effects onthe shallow-water fish assemblage of the Patos Lagoon estuary (Brazil). Estuaries, 27:905-914.

Garcia, C. A. E. (1996), Hydrografic characteristics. In: Seeliger, U.; Odebrecht, C.and Castello, J. P. (eds) Subtropical convergence environments: the coastal and sea in the southwestern Atlantic. Springer, Berlin, pp 18-20.

Glantz, M. H. (2000), Currents of change.. Cambridge University Press, Cambridge,. pp 266.

Grimm, A. M.; Barros, V. R. and Doyle, M. E. (2000), Climate variability in Southern America associated with El Niño and La Niña events. J. Clim., 13:35-58. 
Grimm, A. M.; Ferraz, S. E. T. and Gomes, J. (1998), Precipitation anomalies in Southern Brazil associated with El Niño and La Niña events. J. Clim., 11:28632880.

Haimovici, M.; Castello, J. P. and Vooren, C. M. (1996), Fisheries. In: Seeliger, U.; Odebrecht, C.and Castello, J. P. (eds) Subtropical convergence environments: the coastal and sea in the southwestern Atlantic, pp 183-196.

Hollowed, A. B.; Hare, S. R. and Wooster, W. S. (2001), Pacific basin climate variability and patterns of northeast pacific marine fish production. Prog. Oceanogr., 2001:257-282.

Lehodey, P.; Bertignac, M.; Hampton, J.; Lewis, A. and Picaut, J. (1997), El Niño Southern Oscillation and tuna in the western Pacific. Nature, 389:715-718.

Lu, H.-J.; Lee, K.-T. and Liao, C. H. (1998), On the relationship between El Nino Southern Oscillation and South Pacific albacore. Fish. Res., 39:1-7.

Moller, O. O. J.; Casting, P.; Salomon, J.-C. and Lazure, P. (2001), The influence of local and nonlocal forcing effects on the subtidal circulation of Patos Lagoon. Estuaries, 24:297-311.

Reis, E. G.; Vieira, P. C. E. and Duarte, V. S. (1994), Pesca artesanal de teleósteos no estuário da Lagoa dos Patos e costa do Rio Grande do Sul. Atlântica, 16:69-86.

Reis, E. G. and D'incao, F. (2000), The present status of artisanal fisheries of extreme Southern Brazil: an effort towards community-based management. Ocean Coast. Manage., 43:585-595.
Seeliger, U. (2001), The Patos Lagoon Estuary, Brazil. In: Seeliger, U.and Kjerfve, B. (eds) Coastal Marine Ecosystems of Latin American. Springer Verlag, Berlin, pp 167-182.

Sverdrup, K. A.; Duxbury, A. C. and Duxbury, A. B. (2005), An introduction to the world's oceans, Vol. McGraw-Hill, New York.

Tyler, A. V. (1992), A context for recruitment correlations: why fisheries biologist should still look for them. Fish. Oceanogr., 1:97-107.

Vieira, J. P. (1991), Juvenile mullets (Pisces: Mugilidae) in the estuary of Lagoa dos Patos, RS, Brazil. Copeia, 1991:409-418.

Vieira, J. P. and Castello, J. P. (1996), Fish fauna. In: Seeliger, U.; Odebrecht, C.and Castello, J. P. (eds) Subtropical convergence marine ecosystem. The coast and the sea in the warm temperate southwestern atlantic. Springer Verlag, New York, pp 56-61.

Vieira, J. P. and Scalabrin, C. (1991), Migração reprodutiva da "tainha" (Mugil platanus GUNTHER, 1980) no sul do Brasil. Atlântica, 13:131-141.

Yánez, E.; Barbieri, M. A.; Silva, C.; Nieto, K. and Espíndola, F. (2001), Climate variability and pelagic fisheries in northern Chile. Progr. Oceanogr., 49:581-596. 